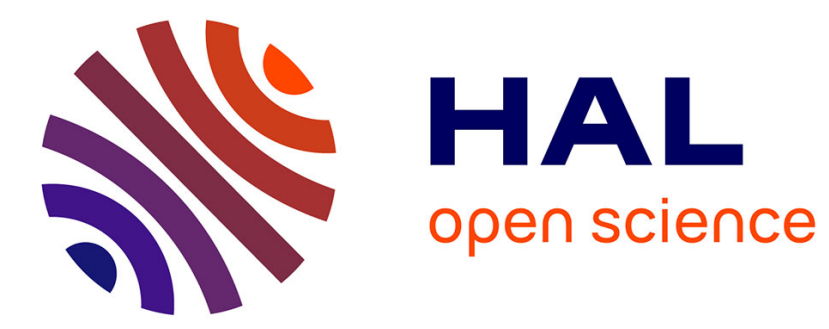

\title{
Vagueness in RAND Licensing Obligations is Unreasonable for Patent Owners
}

\author{
François Lévêque, Yann Ménière
}

\section{To cite this version:}

François Lévêque, Yann Ménière. Vagueness in RAND Licensing Obligations is Unreasonable for Patent Owners. 2009. hal-00488208

\section{HAL Id: hal-00488208}

https://hal-mines-paristech.archives-ouvertes.fr/hal-00488208

Submitted on 1 Jun 2010

HAL is a multi-disciplinary open access archive for the deposit and dissemination of scientific research documents, whether they are published or not. The documents may come from teaching and research institutions in France or abroad, or from public or private research centers.
L'archive ouverte pluridisciplinaire $\mathbf{H A L}$, est destinée au dépôt et à la diffusion de documents scientifiques de niveau recherche, publiés ou non, émanant des établissements d'enseignement et de recherche français ou étrangers, des laboratoires publics ou privés. 

Patent Owners

\author{
François Lévêque, Yann Ménière
}

Working Paper 2009-04

Cerna, Centre d'économie industrielle MINES ParisTech

60, boulevard Saint Michel

75272 Paris Cedex 06 - France

Tél. : 33 (1) 40519000

December 2009 


\title{
Vagueness in RAND Licensing Obligations is Unreasonable for Patent Owners
}

\author{
François Lévêque \& Yann Ménière
}

January 12, 2010

\begin{abstract}
Recent evolutions have called into question the traditional practices of standard-setting organizations (SSOs), especially as regards the licensing of essential patents. In the trail of recent antitrust cases, doubts have been cast in particular on the effectiveness of the current IP policies requiring that essential patent owners commit to licensing their IP on RAND terms, the latter commitments being now perceived as too vague. Against this background, the purpose of this paper is twofold. We first highlight the rationale of the old RAND regime, as well as its effects when it becomes ineffective to mitigate the holdup problem. We then discuss the advantages of requiring more precise commitments. We especially analyze and compare the effects of two new IP policies currently experimented in some SSO: requiring that patent owners commit on a royalty cap as experimented by VITA, and allowing patent owners to choose freely whether to commit on a cap or an exact royalty, as experimented with IEEE-SA.
\end{abstract}


François Lévêque is professor of Law and Economics at Cerna, MINES ParisTech and visiting professor at the Boalt Hall School of Law, University of California at Berkeley (leveque@ensmp.fr)

Yann Ménière is a fellow researcher at Cerna, Ecole des mines de Paris, ParisTech (meniere@ensmp.fr) 


\section{Introduction}

In the past, the number of patents protecting technologies incorporated in standards was small. Patent owners were generally downstream integrated in manufacturing standard-compliant equipment, and their commitment in licensing their intellectual property under reasonable terms was self-evident. Litigation between patent holders and users of standards was unknown. Now, the situation is in the other way round. During the last decade the number of patents reading on standards has increased dramatically ${ }^{1}$ and some are owned by pure R\&D specialists or by pure patent holding companies ${ }^{2}$. Full-blown disputes between users and patent owners are now emerging ${ }^{3}$. At their core is the amount of royalties the former have to pay to the latter to manufacture products in compliance with the standard. Litigation arises because initially patent owners promised a reasonable rate for access to their technology, but as time passes what is reasonable for the licensor appears too high for the licensee and vice versa. There is no longer a consensus between parties involved in standard setting on what 'reasonable' means.

Patent owners' interests are commonly viewed as conflicting with those of standard users. In recent high-profile antitrust cases, patent owners are de-

\footnotetext{
${ }^{1}$ See e.g., Timothy S. Simcoe, Explaining the Increase in Intellectual Property Disclosure, in The Standard Edge - The Golden Mean, Ch. 19, 153-162 (ed. Sherrie Bolin, Ann Arbour, 2007) Simcoe highlights the dramatic increase in patent disclosure in nine standard-setting organizations between 1981 and 2004.

${ }^{2}$ These companies own patents they bought from inventors and seek to enforce their right through the negotiation of licenses and litigation. They are also called "Non Practicing Entities", or more pejoratively "Patent Trolls". For a balanced view on these companies, see Miranda Jones, Permanent Injunction, A Remedy By Any Other Name Is Patently Not The Same: How Ebay v. MercExchange Affects The Patent Right of Non-Practicing Entities, George Mason Law Review, 1035-1070, 2007.

${ }^{3}$ For a brief survey of cases, see infra section 2. For a general presentation, see Thomas F. Cooter, Patent Holdup, Patent Remedies, and Antitrust Responses, 34 Journal of Corporation Law (forthcoming 2009) at Section V.A.; for a short description of cases brought by the FTC, see U.S. Department of Justice and the Federal Trade Commission, Antitrust Enforcement and Intellectual Property Rights: Promoting Innovation and Competition at 43-45 (2007); for a legal analysis of Federal Circuit Court decisions, see Herbert J. Hovenkamp, Patent Continuations, Patent Deception, and Standard Setting: the Rambus and Broadcom Decisions, University of Iowa Legal Studies Research Paper, $\mathrm{n}^{\circ}$ 08-25, June 2008
} 
picted either as villains manipulating the standard-setting process to ransom users $^{4}$ or, in a more neutral view, as strategic agents benefiting from loopholes in the internal rules of a gentlemen's $\operatorname{club}^{5}$. In both cases, patent owners are usually considered to be the primary beneficiaries of the lack of clarity of standard bodies' rule for disclosing patents and licensing them on reasonable terms. However, as this paper shows, patent owners as a whole have an interest in the clarifying of what 'reasonable' terms of licensing means.

\section{RAND promise, patent holdup and ex ante competition}

Standard setting organizations (hereafter, SSOs) aim at defining common technology norms at the industry level. They organize meetings and workgroups wherein engineers discuss the merits of each elementary piece of technology that could be embodied within the future standard. When two or more pieces can achieve the same function, only one piece, supposedly the best one, is selected to be part of the standard. Generally speaking ${ }^{6}$, companies which participate

\footnotetext{
${ }^{4}$ See e.g., Robert Skitol, Concerted Buying Power: Its Potential For Addressing The Patent Holdup Problem In Standard Setting, 72 Antitrust L. J. 727 (2005) at 728 where he states that "generally prevailing policies of standard-setting organizations enable and indeed facilitate gaming the system"); Mark A. Lemley and Carl Shapiro, Patent Holdup and Royalty Stacking, 85 Texas Law Review, 1991, 2007, where the authors notice that the possibility of revenue from holdup has enticed a number of firms into the business not of innovating, but of buying patents and suing to enforce them and showing that holdup is of particular concern when the patent itself covers only a small piece of the product; Joseph Farrell, John Hayes, Carl Shapiro and Theresa Sullivan, Standard Setting, Patents, and Hold-up, 74 Antitrust L. J. 603 (2008), where the authors stress the difference between the reward to a patent holder based on his innovation and patent, and the potential extra return based on holdup.

${ }^{5}$ Philip J. Weiser, Making the World Safe for Standard Setting, University of Colorado Law School Legal Studies Research Paper Series, Working Paper, nº8-06, March 13 (2008). Weiser points out that the model of standard-setting as a club or a quasi-public service by technologists is outdated and that standard-setting bodies must experiment with new approaches to address patent issues.

${ }^{6}$ See Mark A. Lemley, Intellectual Property Rights and Standard-Setting Organizations, 90 California Law Review, 1989 (2002) (studying 29 SSOs and showing that 21 have written policy governing the ownership of property rights including 15 with RAND licensing provisions) and Josh Lerner, Marcin Strojwas and Jean Tirole, The Rules of Standard-Setting Organizations: an Empirical Analysis, The Rand Journal of Economics, Vol. 38, n 4 p. 905-930 (2007)
} 
in this selective process are required by SSOs' bylaws to license the patent protecting their piece of technology, if any, to users according to reasonable and non-discriminatory $\left(\mathrm{RAND}^{7}\right.$, hereafter) terms.

SSOs, however, do not explain, nor define, what does the RAND formula mean ${ }^{8}$. Leaving these words in darkness has not mattered until the recent cases involving Qualcomm. Qualcomm is a US mobile phone chipset company that owns multiple patents on telecommunication standards such as CDMA, WCDMA and HSDPA. It derives about $40 \%$ of its revenue from the licensing of its intellectual property ${ }^{9}$. One of its competitors, Broadcom, alleged that Qualcomm was in violation of section 2 of the Sherman Act by failing to license its technology on RAND terms, although it had committed to do so before its technology was chosen as a standard ${ }^{10}$. Broadcom, along with other companies, including Nokia ${ }^{11}$, also lodged a complaint with the Commission of the European Communities, arguing that the breach of Qualcomm's RAND promise infringes Article 82 of the Treaty. Qualcomm has now settled its antitrust dis(studying 59 SSOs and showing that $60 \%$ ask for RAND terms of licensing in their patent policies).

${ }^{7}$ Another formula is FRAND, where the F stands for 'fair'. This additional adjective does not substantially change the meaning of RAND (see e.g., Mikko Valimäki, 12 European Competition Law Review, 686, 2008) and most of the literature does not distinguish between 'fair' and 'reasonable' (see e.g., Damien Geradin and Miguel Rato, Can standard-Setting lead to Exploitative Abuse? A Dissonant View on Patent Hold-up, Royalty Stacking and the Meaning of FRAND, 3 European Competition Journal (2007) at 113). Our article employs RAND unless a specific source refers to FRAND.

${ }^{8}$ See Lemley, supra note 6 , at 2015 , where he underscores that "While 'reasonable and nondiscriminatory licensing' thus appears to be the majority rule among organizations with a patent policy, relatively few organizations give much explanation of what those terms mean or how licensing disputes will be resolved".

${ }^{9}$ The revenues from licensing Qualcomm's technologies amounted to 1.38 \$ bilion during the 4 th quarter of fiscal year 2008, that is $41.2 \%$ of Qualcomm's overall revenue (see http://www.qualcomm.com/investor/index.html).

${ }^{10}$ The claim was dismissed by the US District Court for the District of New Jersey, reasoning that Qualcomm enjoys a legal monopoly in its patented technology and that its deceptive conduct did not matter under antitrust law because the adoption of a standard would inevitably result in the absence of competition. The Third Circuit reversed the District Court's ruling in appeal, see Broadcom Corp. v. Qualcomm Inc. 501 F.3d 297 (3d Cir. 2007) (recognizing that a firm's deceptive RAND commitment may constitute actionable anticompetitive conduct).

${ }^{11}$ The other plaintiffs are Ericsson, Nokia, Texas Instruments, NEC and Panasonic. The European Commission examined the complaint and initiated formal proceedings against Qualcomm in October 1, 2007 (Case COMP 39/247). 
pute with Broadcom and Nokia ${ }^{12}$.

Stimulated by these battles, legal scholars and economists were quick to debate and to speculate on what reasonable licensing terms ${ }^{13}$ may signify and imply. The mainstream view is that the rationale for RAND is to mitigate holdup and that the R in RAND stands for the level of royalty resulting from competition in advance of standard selection ${ }^{14}$.

The risk of holdup comes from the nature of investments that manufacturers of standard-compliant equipment have to undertake for testing, designating and producing. Usually, these investments are very specific to the chosen standard. As a result, they cannot be easily redeployed to other uses. Their value becomes much lower, and may even be nil, if manufacturers fail to get a license for patents reading on the standard. Because of this lock-in effect, manufacturers are ready to pay a much higher royalty after the standard is adopted than before. To put it another way, patent owners are able to extract more money from their patents once investment made by manufacturers is sunk. In fact, they can obtain as much as the costs of manufacturers to abandon the standard and adopt a new one around a different technology.

\footnotetext{
${ }^{12}$ Broadcom and Qualcomm ended their antitrust disputes on April 26, 2009. This agreement is part of a global settlement that includes the termination of many patent litigations. Like Broadcom, Nokia had also withdrew its complaint to the European Commission as part of a global settlement (see http://www.nokia.com/press/pressreleases/showpressrelease?newsid=1238093) in July 2008.

${ }^{13}$ Unlike reasonableness, the non-discrimination obligation in licensing has not attracted much attention from scholars. Speculations as to its meaning is not widespread. A noticeable exception is Daniel G. Swanson and William J. Baumol, Selection of Compatibility Standards and Control of Market Power Related to Intellectual Property, 73 Antitrust Law Journal 1 at 29 , where they argue that the non-discrimination obligation is a means to mitigate the risk that a vertically integrated licensor would exclude rivals in the downstream market in setting a lower royalty for its indispensable inputs than the royalty it charges itself. Swanson and Baumol show that the so-called Efficient Component Pricing Rule that was forged to ensure a neutral access to railroads and other liberalized networks owned by incumbents may apply: "[A]ny license fee that substantially departs from the ECPR level can be deemed to violate the RAND requirement of nondiscrimination".

${ }^{14}$ For a first formulation of this view see Carl Shapiro and Hal Varian, Information Rules-A Strategic Guide to the Network Economy (1999) at 241. For an elaborated view based on an ex ante auction model, see the very influential paper of Swanson and Baumol, supra note 12 at section 2 B. For a critical analysis of this ex ante auction model, see Damien Géradin, Anne Layne-Farrar and Jorge Padilla, Competing Away Market Power? An Economic Assessment of Ex Ante Auctions In Standard Setting, 4 European Competition Journal (2008), 443.
} 
Such an amount can be huge. Firstly, in addition to sunk investments the withdrawal of a standard also entails the loss of network effects. Indeed, the decrease in technological compatibility lowers the size of users groups that can be interconnected and the number of complementary products and services they may enjoy. Secondly, setting a new standard is a long process. Manufacturers are likely to be deprived of income for several years. By contrast, before the standard is set and investments are sunk, the value of a patent protecting a technology that is a candidate to be incorporated in the standard only depends on whether alternative technologies are available and what their relative performances are. To simplify ${ }^{15}$, if the technology has a better substitute, the patent's value is zero; if it has no substitute, the patent's value equals the entire benefit it creates for users; if there is a second best technology, the patent's value is worth the gain for users to use the best technology rather than its closest substitute. In other terms, before the standard is set the value of patents is constrained by the strength of technological competition. The royalty patent owners can expect if their technology is selected depends on the incremental contribution of their invention. Note that this value is exactly how the patent system is supposed to reward innovators. After the standard is set and investments are made, however, the patent owners can extract a supra-normal royalty because their patents have become essential and users captive.

A complementary interpretation consists in viewing the RAND promise as a waiver of injunctive relief ${ }^{16}$. According to this interpretation, the patent holder

\footnotetext{
${ }^{15}$ The patent holder is unable to extract the whole value of his invention from users because of the following obstacles, inter alia: licensing is costly, patent validity is not one hundred percent sure, perfect discrimination to annihilate the deadweight loss is impossible, licensees enjoy some bargaining power. See e.g., Swanson and Baumol, supra note 12, where they model the level of reasonable royalties in including the costs of licensing in addition to the value of the patented technology relatively to the next best alternative. Farrell, Hayes, Shapiro and Sullivan, supra note 4, develop another model in which they take into account the likelihood that the patent be invalid and the respective bargaining powers of the licensor and the licensee.

${ }^{16}$ See Joseph S. Miller, Standard Setting, Patents and Access Lock-in: RAND Licensing and the Theory of the Firm, 40 Indiana Law Review 351, 2007. Miller interpretes the RAND promise at 21 "as an irrevocable waiver of the patentee's right to extraordinary relief for in-
} 
commits not to seek a Court injunction and treble damages against unauthorized access. He therefore abandons ex ante his most powerful bargaining advantage for negotiating royalties ex post. In case negotiation fails, litigation may ensue but the users of the standard will expect not to be confronted with extraordinary remedies. The parties will leave to the judge the setting of a reasonable rate $^{17}$. Note that the rationale here for RAND remains to mitigate holdup, since a preliminary or permanent injunction and enhanced damages are the main instruments of the patent owners' arsenal to leverage supra-normal royalties.

An alternative interpretation of the RAND promise ${ }^{18}$ is that it provides a safeguard against refusal to deal ${ }^{19}$. According to this interpretation, the patent

fringement" and using transaction cost economics to demonstrate that RAND is a governance structure that reallocates the access right from the patentee to users. For a critic of Miller's theory, see Damien Geradin and Miguel Rato, supra note 7, at 15. They argue that Miller's position is wrongly based on the premise that U.S courts would automatically grand permanent injunctions against the use of the essential patents by standard-compliant manufacturers.

${ }^{17}$ The setting of reasonable royalties is not unfamiliar to judges. In patent infringement cases, when the patentee cannot demonstrate lost profit, royalties are determined by the court by imagining that a hypothetical negotiation takes place on the date such infringement began and calculating what would have been the value chosen by the parties. In practice, this re-enacting is based on the review of a whole series of parameters, such as the rates of royalties paid for similar inventions, the term and scope of the patent, and the impact on licensee's sales. Judges use as reference a list including 15 such factors. This list is known as 'Georgia-Pacific factors' because it was used for the first time in 1970 in the Georgia-Pacific Corp. v US Plywood Corp. case, 318 F Supp 1116, 1120 (SDNY 1970), judgment modified on other grounds by Pacific Corp. v. U. S. Plywood-Champion Papers, Inc., 446 F.2d 295 (2d Cir. 1971). For an extension of the Georgia-Pacific factors to a standard setting context, see Anne Layne-Farrar, A. Jorge Padilla and Richard Schmalensee, Pricing Patents for Licensing in Standard Setting Organizations: Making Sense of FRAND Commitments, 74 Antitrust Law Journal 3.

${ }^{18}$ See Geradin and Rato, supra note 7 at 11: "A FRAND commitment is intended to prevent an outright refusal to license or the setting of royalty rates and other terms and conditions so high as to suggest an intent by the IPR owner to do indirectly what it has committed not to do directly: refuse to license its essential IPR to other firms." See also Damien Geradin, Standardization and Technological Innovation: Some Reflections on Ex-Ante Licensing, FRAND, and the Proper Means to Reward Innovators, 29 World Competition, 511 (2006) at 4: "The only material consequence of a FRAND commitment is that the patent holder waives its rights to engage in good faith negotiations to license," and at 5: "The main purpose behind FRAND is thus to ensure that any standard adopted remains available for implementation by all companies willing to take advantage of the opportunity to negotiate and enter into a license agreement. FRAND therefore aims at preventing an outright refusal to license."

${ }^{19}$ This interpretation mainly focuses on the R term of RAND. Like most authors Geradin and Rato, supra note 7, do not elaborate much on the meaning of non-discrimination. 
owner commits to not refusing access to his intellectual property, and therefore to not foreclosing the access to the whole standard, to any third party. Of course, for such a commitment to be effective, it must also encompass so-called constructive refusals to deal, that is, the setting of so extreme price and non price conditions that they will have the same effect as a naked refusal to deal (i.e., the blocking of access to input essential ${ }^{20}$ for practicing the standard). For the proponents of this interpretation RAND is a flexible tool that ensures patents reading on a standard are available without unduly constraining licensors ${ }^{21}$. Its rationale is not to mitigate holdup. Moreover, holdup is denied by the proponents of the alternative interpretation of RAND to be a significant phenomenon in standard setting ${ }^{22}$. As a matter of fact, we do not know. Empirical evidence on holdup attempts is lacking and anecdotal evidence contradictory ${ }^{23}$.

Facts are clearer regarding the theoretic interpretation of $\mathrm{R}$ in RAND as the outcome of a competition process ${ }^{24}$ : Up to now the selection of technologies to

\footnotetext{
${ }^{20}$ Note an interesting parallel between the refusal to deal interpretation of RAND and antitrust remedies in case of refusal to license. For instance, in EC Commission v. Microsoft (Case COMP /C-3/37.792), where the European Commission ordered the Redmond firm to disclose its specifications for the protocols used by Windows workgroup servers, Microsoft was allowed to charge reasonable and non-discriminatory royalties for licensing the protocols. For a discussion on this remedy, see François Lévêque, Innovation, Leveraging and Essential Facilities: Interoperability Licensing in the EU Microsoft Case, World Competition 28 (1), 71-91 (2005). For a parallel between the EU Microsoft case involving a de facto standard and antitrust cases involving cooperative standards set by SSOs, see Anne Layne-Farrar, Antitrust and Intellectual Property Rights: Assessing The Link Between Standards And Market Power, Antitrust, Vol. 21, $\mathrm{N}^{\circ}$ 3, 42-48 (2007).

${ }^{21}$ See Geradin and Rato, supra note 7 at 10 .

${ }^{22}$ See Geradin, supra note 17 at 6 (arguing that there is a misleading conception of the holdup problem); Damien Geradin and Anne Layne-Farrar, Logic and Limits of Ex-Ante Competition in a Standard Setting Environement, 3 Global Competition Policy 1 (2007) (concluding that it is unlikely the problem of patent holdup is wide spread); and J. Gregory Sidak, Patent Holdup and Oligopsonic Collusion in Standard-Setting Organizations, available at http://papers.ssrn.com/sol3/papers.cfm?abstract_id=1081997, at 3 (expressing his skepticism about the existence and empirical significance of patent holdup).

${ }^{23}$ See e.g., Daniel J. Weitzner, Supplemental Comments, Joint Rountables on Competition and Intellectual Property Law and Policy in the Knowledge-Based Economy: Standards and Intellectual Property, November 6, 2002 available at http://www.w3.org/2002/11/15-doj-ftcipr-weitzner-suppl.html. Weitzner notes that the Telecommunications Industry has observed only a 'handfull' of holdups in the setting of 600 standards while the World Wide Web consortium has observed that holdup has been a real problem, estimating its presence in $10 \%$ of cases.

${ }^{24}$ See supra note 13.
} 
be incorporated in the standard has not been based on the relative price and non-price conditions of future licences ${ }^{25}$. Except for a few very recent $\operatorname{cases}^{26}$, information on neither the level of royalties nor on restrictive use is signalled by members of SSOs during the discussions on the technologies to choose. At best, the available economic information for the selection between competing technologies is limited to whether there would be no royalty or a reasonable royalty. Three main explanations are given for this absence of price signalling. Firstly, participants at the meetings for developing a standard are engineers and technical officers. They are not familiar with legal and marketing aspects related to licensing, nor are they authorized to make decisions on licensing terms ${ }^{27}$. Secondly, SSOs often prohibit their members from exchanging information on royalties for fear of antitrust liability ${ }^{28}$. This rule is based on the perception

\footnotetext{
${ }^{25}$ See Lemley, supra note 8 at1964-1965: "Virtually no SSO specifies the terms on which the licenses must be granted beyond the vague requirement that they be 'reasonable' and 'nondiscriminatory' [...] The result is uncertainty over the cost and scope of patent licenses that may not prove much better than having no policy at all".

${ }^{26}$ See e.g., the VITA's patent policy, as detailed in this article in section 2, mandating its members to declare in advance the maximum level of royalty as well as the most restrictive obligations of its future license.

${ }^{27}$ See Richard Holleman, A Response: Government Guidelines Should not Be Issued in Connection with Standard Setting, public comment, Competition and Intellectual Property Law and Policy in the Knowledge-Based Economy, February 6 - November 6, 2002 available at http://www.ftc.gov/opp/intellect/020418richardjholleman2.pdf, at 4. Accordingto Holleman, the discussion in the SSO "should be focussed on technical issues-not licensing terms and conditions. Otherwise, individuals who are not knowledgeable about or authorized to make decisions about licensing terms will be placed in a position of having to do so"; See also Skitol, supra note 4 at 4 . Skitol describes the view of SSOs as considering that "Individuals who participate in standard setting are, for the most part, engineers unschooled in business considerations and unequipped to address the costs and related competitive implications of their technical specification".

${ }^{28}$ See e.g., Michael G. Cowie and Joseph P. Lavelle, Patents Covering Industry Standards: The Risks to Enforceability Due to Conduct Before Standard-Setting Organizations, 30 AIPLA Quaterly Journal 95,100 (2002) at 102: "SSOs have been reluctant to specify or become involved in setting royalty rates for patented technology for fear that they will be accused of price fixing or another violation of the antitrust laws"; Amy A. Marasco and Elizabeth Dodson, Invention and Innovation: Protecting Intellectual Property in Standard-Setting, 2 Journal IT Standards and Standardization Research 49, 50 (2004) at 50. They observe that "discussing licensing issues may impose a risk that the [SSO] and the participants will become targets of allegations of improper antitrust conduct"; Farrell, Hayes, Shapiro and Sullivan, supra note 4, at 25: "SSOs have historically been fearful of the possible antitrust implications of housing royalty negotiations"; Grazyna Piesiewicz and Ruben Schellingerhout, Intellectual Property Rights in Standard Setting from a Competition Law Perspective, Competition Policy Newsletter, Number 3 (2007) at 37. The authors point out that in the 90s "Many standards setting bodies adopted rules aiming to prevent antitrust liability, including rules forbidding
} 
that joint negotiation on licensing terms falls under a per se prohibition due to its price-fixing flavour. Thirdly, the value of a patent is difficult to figure out $^{29}$ before the standard is set. The extent and pace of the standard adoption by users and the intensity of competition with other standards or with non-standardized products are difficult to forecast before the standard is implemented. The uncertainties around the markets of standard-compliant products are high at the moment of standardization. Note that this third reason is the only objective obstacle to making the technological competition in standard setting more economically based. Technologists participating to the meetings during the standard process can be helped by colleagues of their companies with better knowledge and expertise on patents and markets. This obstacle is practical and cultural ${ }^{30}$. The legal obstacle is overstated ${ }^{31}$, too; in fact, it is currently eroding $^{32}$. Unilateral announcements of the price and non-price attributes of licensing in advance and collective negotiation on royalties' are different matters, even though information exchange can facilitate collusion. Moreover, the antitrust authorities attitude vis-à-vis the disclosure of the terms of licensing before the technologies are chosen has changed. Both US antitrust agencies have declared they will review joint negotiation on royalties under the rule of reason $^{33}$. In the European Union, the European Commission has indicated that discussions about the terms and conditions of licenses to patents essential to a standard".

${ }^{29}$ See e.g., Geradin and Rato, supra note 7, at 29: "the value of an invention is unclear at the moment of standardization. The significance, technical merit and full value of an invention covered by IPR may only be revealed over time as the standard is implemented"; Miller, supra note 14, at 16: "What understandardized products will discipline the price of standardized products early in the product cycle, and how will that change as more people adopt the standardized product ? [...] Calibrated royalty rates should take account of the answers to these and myriad other patent and market questions, but most of the answers will not be known (or known in sufficient detail) until after the SSO has established the standard and producers have begun selling standardized products".

${ }^{30}$ See Weiser, supra, note 5 at 28.

${ }^{31}$ See Skitol supra note 4 at 735 . He argues that the concern of SSOs vis-à-vis antitrust is based on a misunderstanding of current antitrust law.

${ }^{32}$ See Weiser, supra, note 5 . Weiser shows in Part II how antitrust law as it applies to standard-setting bodies has changed from a posture of skepticism to one of presumptive endorsement.

${ }^{33}$ Deborah Platt Majoras, Chair, FTC, Address at Stanford University Law Conference on Standardization and the Law, Recognizing the Pro competitive Po- 
companies are free to fix royalties before the standard is set ${ }^{34}$.

\section{Uncertainty about reasonableness, SSOs IP policies and the fear of holdup}

As seen above, the R in RAND remains obscure because SSOs' bylaws are mute on its definition and prices are not signalled during the standard setting process. However, this observation is delivered from an external standpoint. What seems unclear for outsiders could be relatively obvious for the members of SSOs. The reason is that they often share past experience. Standard setting is usually a repeated process for technology progresses through time. For instance, the standards MPEG 2, MPEG 3 and MPEG 4 have been defined to follow the succession of technological generations in coding moving pictures and associated audio. What is reasonable for a future license may therefore simply mean the setting of terms of licensing that are similar to those of the previous version of

tential of Royalty Discussions in Standard Setting, September 23, (2005) available at http://www.ftc.gov/speeches/majoras/050923stanford.pdf at 7. Majoras suggests that "joint ex ante royalty discussions that are reasonably necessary to avoid hold up do not warrant per condemnation"; Letter from Thomas O. Barnett, Assistant Attorney General, DoJ, to Robert Skitol, (Oct. 30, 2006) available at http://www.usdoj.gov/atr/public/busreview/219380.htm, at note 7. Barnett indicates that the Department would evaluate any collective negotiation and discussion of royalty terms "under the rule of reason because such practices could be pro competitive". See also Antitrust Modernization Commission, Report and Recommendations, available at http://govinfo.library.unt.edu/amc/report_recommendation/amc_final_report.pdf at 13 . The Commision recommends that "Joint negotiations with intellectual property owners by members of a standard setting organization with respect to royalties prior to the establishment of the standard, without more, should be evaluated under the rule of reason".

${ }^{34}$ See Commission Notice Guidelines on the application of article 81 of the EC Treaty on technological transfer agreements, OJC 291 13-10-2000, 1-44 at $\S 225$ : "Undertakings setting up a technology pool that is compatible with Article 81, and any industry standard that it may support, are normally free to negotiate and fix royalties for the technology package and each technology's share of the royalties either before or after the standard is set"; Neelie Kroes, European Commissioner for Competition Policy Being Open about Standards, Open Forum Europe, Brussels, 10th June 2008, available at http://europa.eu/rapid/pressReleasesAction.do?reference $=\mathrm{SPEECH} / 08 / 317 \&$ format $=\mathrm{HTML}$

\&aged $=0 \&$ language $=E N \&$ guiLanguage $=e n$. Commissioner Kroes states at 4 that "Standards bodies can very often require disclosure [of ex ante royalty rate] without fear of competition law intervention". For an overview on the application of EC Article 81 to standard setting agreements, see Piesiewicz and Schellingerhout, supra note 25; for an overview on the application of EC Article 82, see Geradin and Rato, supra, note 7 at 38-53. 
the standard. Generally speaking, sharing a common past and belonging to the same community help members to find a natural point of convergence in the absence of explicit information. An example of such a focal point ${ }^{35}$ in the case of standards set by users is as follows: The royalty per patent will not exceed $5 \%$ of the value of standard compliant products divided by the number of patents reading on the standard.

We must aknowledge, therefore, that R in RAND conveys an understandable message to the participants of the standard-setting process. Furthermore, we must also aknowledge that such a commitment is self-enforcing. From a static perspective, a patent owner's interest is not to comply with his commitment once the users are locked into to the standard. However, insofar as standard setting is a repeated event gathering similar participants, the implicit promise can be sustainable and robust. Take the example of the focal point just mentioned. The owner of a patent reading on a standard may not have any interest in holding up the other users because tomorrow it may be his turn to be held up as a user of subsequent versions of the standard for which he will have no, or fewer, patents.

We therefore do not pretend that the meaning of a reasonable royalty is so vague that the RAND commitment is worthless. Our point is rather that, assuming RAND encapsulates the objective to mitigate holdup, this mechanism is now likely to be partly broken. The reasons are twofold.

Firstly, the audience of standard setting processes is larger and more heterogeneous than ever before. Newcomers from other countries or from other industries have been prompt to join historical members of SSOs once their companies became more global and their technology more converging. As new participants, however, they do not automatically share the same understanding of

\footnotetext{
${ }^{35}$ In game theory parlance, this point is said to be focal. See Thomas C. Schelling, The Strategy of Conflict, Harvard University Press, (1960) at 57, describing "focal point [s] for each person's expectation of what the other expects him to expect to be expected to do".
} 
RAND as incumbents. Moreover, manufacturers of standard compliant products are no longer the only members of SSOs and the single owners of patent reading on standards. A few companies whose business model is to monetize their intellectual property rights have also came on board. They are specialized in $\mathrm{R} \& \mathrm{D}$ or could even be pure patent holding companies. These newcomers have less incentives than users for disciplining the level of royalties, including users who hold patents ${ }^{36}$. They do not produce standard compliant products, so they do not have to pay royalties to others. What they see as a reasonable level of royalty may not be found reasonable at all by the other participants.

Secondly, even though up to now the number of litigations involving deviations from RAND commitments has been extremely low they have drawn much attention from the business community. They have been highly publicized through law and professional journals and through multiple hearings and conferences $^{37}$. Broadcom v. Qualcomm ${ }^{38}$ is the iconic case because royalties in

\footnotetext{
${ }^{36}$ See David Teece and Ed Sherry, Standards Setting and Antitrust, 87 Minnesota Law Review (2003) at 1929, where the authors discuss the conflicting incentives of SSOs' participants; Damien Geradin, What's wrong with royalties in high technology industries? TILEC Discussion Paper Series (May 2008) available at http://papers.ssrn.com/sol3/papers.cfm?abstract_id=1104315 . Geradin examines different settings of ownership of essential patents reading on standard depending on whether owners are vertically integrated, pure manufacturers or pure R\&D firms.

${ }^{37}$ See e.g., US Department of Justice and Federal Trade Commission Hearings on Competition and Intellectual Property Law and Policy in the Knowledge-Based Economy (hereinafter DoJ/FTC Hearing) available at http://www.ftc.gov/opp/intellect/index.shtm (in particular, Standard-Setting Practices: Competition, Innovation and Consumer Welfare (April 18, 2002); Antitrust Law and Patent Landscape (November 6, 2002)); European Commission Intellectual property Rights and ICT Standards, 19 November 2008, (in particular, Panel 1 The interface between ICT standardization policy, intellectual property and competition law); Kroes, supra note 31; Majoras, supra note 30; J. Thomas Rosh, Commissioner Federal Trade Commission, Patent Troll, Broad Brush Definition and Law Enforcement Ideas, Newport Summit on Antitrust and Economics, May 31, 2008; available at http://www.ftc.gov/speeches/rosch/080531roschlecg.pdf; , J. Thomas Rosh, Commissioner Federal Trade Commission, Section 2 and Standard Setting: Rambus, N-Data \& The Role of Causation, Law Seminar International's 4th Antitrust Conference on Standard Setting and Patent pools, Arlington, October 2, 2008 available at http://www.ftc.gov/speeches/rosch/081002section2rambusndata.pdf; Gerald F. Masoudi, Deputy Assistant Attorney General, Antitrust Division, Objective Standards and the Antitrust Analysis of SDO and Patent Poll Conduct, Annual Comprehensive Conference on Standards Bodies and Patents Pools, Law Seminars International, Arlington, October 11, 2007 available at http://www.usdoj.gov/atr/public/speeches/227137.pdf.

${ }^{38}$ See supra note 10.
} 
mobile telecommunications account for hundreds of millions of dollars. Broadcom's complaint alleged, among other things, that Qualcomm made and broke an intentionally false promise to license proprietary technology on RAND terms. The Third Circuit Court held that such a deceptive conduct may give rise to antitrust liability $^{39}$. It ordered the District Court of New Jersey to reinstate the case, which is now pending. The antitrust case before the European Commission, initially involving Broadcom and 5 other companies ${ }^{40}$ who are Qualcomm's competitors or licensees, is still at the investigation phase. No statement of objections specifying the abuses alleged against Qualcomm has yet been issued. This case has attracted a lot of attention because Qualcomm may be found liable under article $82(\mathrm{a})^{41}$, an article of the EC competition law that deals with unfair prices and is rarely enforced ${ }^{42}$, for the breach of its RAND commitment.

Another series of cases has raised doubts in the business community as to the binding force of the commitments made by holders of patents reading on a standard. They differ from the Qualcomm case because the alleged breach of the promise is made here by subsequent owners of the patent. The most well known case belonging to this second line of breach of RAND cases is FTC v. N-Data ${ }^{43}$. N-Data is a patent licensing company that owns patents reading

\footnotetext{
${ }^{39}$ See supra note 36 at 24 : "We hold that (1) in a consensus-oriented private standard-setting environment, (2) a patent holder's intentionnally false promise to license essential proprietary technology on FRAND terms, (3) coupled with an SDO's reliance on that promise when including the technology in a standard, and (4) the patent holder's subsequent breach of that promise, is actionable anticompetitive conduct".

${ }^{40}$ Broadcom, Nokia, see supra note 10.

${ }^{41}$ European Commission, Antitrust: Commission initiates formal proceedings against Qualcomm, MEMO/07/389 (Press release), Octobre 1, 2007 available at http://europa.eu/rapid/pressReleasesAction.do?reference=MEMO $/ 07 / 389 \&$ format $=$ HTML\& aged $=0 \&$ language $=\mathrm{EN} \&$ guiLanguage $=$ en.

${ }^{42}$ For a general overview on article $82(\mathrm{a})$ 's enforcement, see Massimo Motta and Alexandre de Streel, Exploitative and Exclusionary Excessive Prices in the EU Law, in Claus-Dieter Ehletman and Isabela Atanasiu (eds), European Competition Law Annual 2003, What is an Abuse of a Dominant Position?, Oxford, Hart Publishing, 2006. For a discussion on article 82(a) in the standard-setting context, see Géradin and Rato, supra note 7 at 46-50.

${ }^{43}$ After the FTC decision in N-Data, the American Antitrust Institute petitioned the FTC to invest a similar renegation of the initial terms of licensing by a patent-holding company, Rembrandt Inc. See Request for Investigation of Rembrandt, Inc. For Anticompetitive Conduct That Threatens Digital Television Conversion, American Antitrust Institute, March 26, 2008 available at
} 
on a fast Ethernet standard ${ }^{44}$. The patents were originally owned by National Semiconductor who committed in 1994 to license them for a one-time paid-up royalty of $\$ 1000$. Soon after its acquisition of the patents in 2003, N-Data sought to renegotiate the royalties and impose a higher price. The Ethernet standard incorporating the Nqational Semiconductor's technology was then already "used by almost every American consumer who owns a computer" 45 . The FTC ${ }^{46}$ found N-Data violated Section 5 of the FTC Act and a consent decree reestablished the one-time fee of $\$ 1000$.

A last category of cases that has instilled doubts for standard users about RAND as an effective safeguard against holdup is provided by cases of patent ambush, that is, whenever a patent owner conceals his patent during the standardsetting process and subsequently asserts it is infringed upon use of the standard. Here, the most commented-on ${ }^{47}$ case is the Rambus one ${ }^{48}$. In the FTC liability opinion in Rambus ${ }^{49}$, Commissioner Pamela J. Harbour recites the basic facts as follows. Rambus, a developer and licensor of computer memory technologies, participated during the 1990s to a standard-setting process organized by the Joint Electron Device Engineering Council (JEDEC, hereafter). This SSO

http://www.antitrustinstitute.org/archives/files/AAI\%20Petition\%20Rembrandt\%203.26.08 032520082308.pdf.

${ }^{\overline{4}}$ The N-Data's patents cover a piece of technology, so-called Nway, which was invented by National Semiconductors and incorporated into the 802.3 Ethernet Standard set by IEEE in 1994.

${ }^{45}$ Statement of the FTC in the Matter of Negotiated Data Solutions LLC, file $\mathrm{n}^{\circ} 05110094$ at 1 .

${ }^{46}$ The complaint against N-Data was issued on a 3-2 vote. Deborah Platt Majoras dissented from the decision because "The facts do not support a determination of antitrust liability" (Dissenting Statement of Chairman Majoras, in the Matter of Negotiated Data Solutions LLC, file $\mathrm{n}^{\circ} 05110094$, p.2). The Commissioner William E. Kovacic opposed the decision for more doctrinal reason, in particular because the basis of liability does not distinguish between unfair method of competition and unfair acts or practices (Dissenting Statement of Commissioner William E. Kovacic, in the Matter of Negotiated Data Solutions LLC, file $\mathrm{n}^{\circ}$ 05110094).

${ }^{47}$ See comments from e.g., Skitol, supra note 4 at $731-732$; Rosh, note 34 ; Thomas F. Cotter, Patent Holdup, Patent Remedies, and Antitrust Responses, University of Minnesota Law School, Legal Studies Research Paper Series, Research Paper n ${ }^{\circ}$ 08-39, September 2008 at $45-47$.

${ }^{48} \mathrm{~A}$ less recent and less discussed case is Dell, In the Matter of Dell Computer Corp., 12 FTC 616 (1996).

${ }^{49}$ Pamela Jones Harbour, Commissioner of the FTC, In the Matter of Rambus Inc., Docket $\mathrm{n}^{\circ} 9302$. 
required of its members the disclosure of patents (or patent applications) and RAND licensing commitments. Rambus capitalized on this policy and on the expectations of the other members of JEDEC in several ways. It concealed the existence of its patents and patent applications, it instilled the belief among other participants that it was not seeking patents that would cover the standard, and it used the information gained during the standard-setting process to word the claims of its patents to ensure that they would cover the standard. When the standard was adopted and the market was locked in, Rambus revealed its patents through patent infringement lawsuits against JEDEC members who practiced the standard. The FTC found this deceptive conduct of Rambus violated section 2 of Sherman Act. It constituted monopolization because in a hypothetical world free from Rambus' course of conduct "JEDEC either would have excluded [its] patented technologies from the JEDEC DRAM standards, or would have demanded RAND assurances, with an opportunity for ex ante licensing negotiations". This causal link between Rambus' deceptive conduct and Rambus acquisition of monopoly power was objected to the District of Columbia Circuit on appeal and the FTC's decision was overturned ${ }^{50}$. According to the Court there is insufficient evidence that Rambus' technology would not have been chosen if it had disclosed its patents, and the loss of an opportunity to seek favourable terms is not an antitrust violation ${ }^{51}$. In other words, whenever the inclusion of an alternative technology is not clearly demonstrated as the 'but for' scenario, deceptive concealment of patents does not expose the member of

\footnotetext{
${ }^{50}$ The FTC filed a petition for review of the appelate decision in Rambus matter with the US Supreme Court on November 24, 2008, but it was rejected on February 23, 2009. The seven-year battle is now definitely terminated.

${ }^{51}$ Rambus Inc. v. Federal Trade Commission, F.3d, 2008 WL 1795594, US Court of Appeal for the District Court of Columbia, $\mathrm{n}^{\circ}$ 07-1086 (April 22, 2008) at 11: "We [...]conclude that the Commission failed to demonstrate that Rambus' conduct was exclusionary under settled principles of antitrust law" and at 18 "[T] he Commission expressly left open the likelihood the JEDEC [the concerned SSO] would have standardized Rambus's technologies even if Rambus had disclosed its intellectual property. Under this hypothesis, JEDEC lost only an opportunity to secure a RAND commitment from Rambus. But loss of such commitment is not a harm to competition from alternative technologies in the relevant markets".
} 
the SSO to antitrust liability.

Patent ambush cases have an important consequence on RAND effectiveness to remedy holdup. It reminds us of a trivial aspect: RAND can be effective only insofar as the members of the SSOs comply with the disclosure obligation. Whenever this other basic rule of SSOs' IP policy gives room to gaming, RAND is a poor safeguard against holdup ${ }^{52}$. Moreover, it is important to keep in mind that patent owners who stay outside the standard-setting process are not bound by any rules of the SSOs. If their protected technology is incorporated into the standard, they can decide on the licensing terms they want. Only mismanagement (e.g., the SSO decided to incorporate a technology in the standard without checking in the patent office's database if the technology was patented by a non-member of the SSO) or bad luck (e.g., the checking was unable to reveal the existence of a patent because the application was not yet disclosed) can be invoked by the SSO if its members are held-up.

To respond to the growing uncertainty on reasonableness of terms of licensing, several SSOs have recently proposed and adopted innovative intellectual property policies. They consist in offering the possibility for patent owners to commit on a maximum royalty and in choosing within a menu of different commitments. The idea of capping royalties before technologies are selected in the standard is owed to the VMEbus International Trade Association (VITA,

\footnotetext{
${ }^{52}$ In fact it is difficult to find robust disclosure rules. Participants to SSOs meetings do not know about granted patents and ongoing patent applications of their companies (see, e.g., Farrell et al., supra note 4 at 21), search of patents is difficult (see, e.g., Géradin and Layne-Farrar supra note 20 at 6), and firms with large patent portfolios regularly loose track of valuable patents in their possession (see, e.g., Kevin G. Rivette and David Kline, Rembrands in the Attic : Unlocking the Hidden Value of Patents, Harvard Business School Press, November 1999). As pointed out by Skitol, supra note 4 at 732 , "A blanket or unqualified disclosure requirement may be unacceptable to most participants if it implies a duty to search a company's entire patent portfolio (which may encompass many thousands of patents), identify every patent that might be implicated by a proposed standard whose specifications are still under development, and than disclose all such possible situations. On the other hand, a disclosure requirement limited to patents actually known to personnel participating in the standard setting (without a search duty) would not be enforceable as a practical matter and invites game-playing through patent's owners selection of participating personnel with minimal knowledge of the company's portfolio".
} 
hereafter), a non-profit organization that promotes architectures based on the VMEbus computer technology. Through its standards development subcommittee, it has created more than thirty standards in the past ten years ${ }^{53}$. In January 2007, VITA approved a new patent policy ${ }^{54}$ that requires, inter alia ${ }^{55}$, its members to disclose the maximum royalty rate they will demand for their potentially essential patents ${ }^{56}$. The commitment is irrevocable. However, the patent owners are free to submit subsequent declarations with lower rates. Unlike in VITA's policy, declaring a royalty cap is just an option amongst others possibilities in the recently reformed policy of the standard association of the Institute of Electrical and Electronics Engineers (IEEE, hereafter) ${ }^{57}$. The alternative choices for member of this large ${ }^{58}$ SSO includes 5 main options: a declaration of non-assertion of its patents (i.e., unconditional guarantee of free use); a royalty free license with all other terms and conditions on a RAND ba-

\footnotetext{
${ }^{53}$ See http://www.vita.com/vso-stds.html at the date of November 24, 2008.

${ }^{54}$ See VSO Policies and Procedures, version 2.4, January 2008, section 10.0 at 12-15 (hereinafter VITA patent policy) available at http://www.vita.com/vso-pp-r2d4-clean.pdf. The new VITA patent policy was sent to the US DoJ antitrust department for a business review letter that was issued in October 30, 2006. See Justice Department will not oppose proposal by standard-setting organization on disclosure and licensing of patents, Letter from Thomas O. Barnett, Assistant Attorney Gen., U.S. Department of Justice, to Robert A. Skitol (Oct. 30, 2006), available at http://www.usdoj.gov/atr/public/busreview/219380.pdf; see also Press Release, U.S. Department of Justice, Justice Department Will Not Oppose Proposal by Standard-Setting Organization on Disclosure and Licensing of Patents (Oct. 30, 2006), available at http://www.usdoj.gov/atr/public/press_releases/2006/219379.pdf.

${ }^{55}$ In addition to the maximum royalty, VITA patent policy also requires the members to declare the most restrictive terms of their future license. Of course, it also includes a detailed obligation of patent disclosures. Last but not least, an arbitration procedure and a system of penalties are set to assess and sanction to comply with the policy.

${ }^{56}$ VITA Patent Policy, supra note 51 at 14: "Each [...] Member must declare he maximum royalty rate for all patent claims that the VITA Member Company he or she represents (or its Affiliates) owns or controls and that they may become essential to implement the ffuture standard]" and also at 3 of the Appendix: "The VITA Member Company will grant a license $[\ldots]$ to all interested parties with a royalty rate that will not exceeed : USD \$ or $\%$ of product price per unit".

${ }^{5} \overline{\overline{7}} \overline{\mathrm{Se}}-\overline{\mathrm{IEE}} \overline{\mathrm{E}}-\overline{\mathrm{S}} \overline{\mathrm{A}}$ Board Bylaws (hereinafter, IEEE patent policy) available at http://standards.ieee.org/guides/bylaws/sect6-7.html\#6. As VITA patent policy, IEEE patent policy was reviewed by the Antitrust Division of the Department of Justice. See letter of Thomas O. Barnett to Michael A. Lindsay, April 30, 2007 available at http://www.usdoj.gov/atr/public/busreview/222978.htm.

${ }^{58}$ IEEE-SA is a member of the American National Standard Association. It gathers more than 20.000 participants and each year conducts over 200 standard ballots.
} 
sis; a royalty cap with all other terms and conditions on a RAND basis ${ }^{59}$; a reasonable royalty with all other terms and conditions on a RAND basis; no licensing assurance (i.e., no information on the licensing intentions). Several $\mathrm{SSOs}^{60}$ now offer a menu of options of royalty commitments to their members instead of imposing RAND licensing as a single requirement.

The model below provides a first theoretical assessment of these new policies. Before describing it, it is worthwhile to briefly analyse the economic effects of holdup. The most intuitive one is the losses the industrial users and consumers entail because of the supra-normal royalties. The former will be unable to recoup the entirety of their investments, whereas the latter will lower their consumption of standard-compliant products ${ }^{61}$. This effect, however, is not the most significant one. As mentioned earlier, the number of cases thus far has been very small. On the other hand, those cases have been highly publicized, and therefore the fear of being held-up is likely significant now. Herein lie the main effects. Knowing ex ante, they could be held up ex post, investors adopt sub-optimal strategies ${ }^{62}$. They may decide to reduce their level of investment

\footnotetext{
${ }^{59}$ See IEEE patent policy, supra note 56, at section 6.2: "The patent licensing commitment 'shall be either: a) A general disclaimer to the effect that the Submitter without conditions will not enforce any present or future Essential Patent Claims against any person or entity making, using, selling, offering to sell, importing, distributing, or implementing a compliant implementation of the standard; or b) A statement that a license for a compliant implementation of the standard will be made available to an unrestricted number of applicants on a worldwide basis without compensation or under reasonable rates, with reasonable terms and conditions that are demonstrably free of any unfair discrimination. At its sole option, the Submitter may provide with its assurance any of the following: (i) a not-to-exceed license fee or rate commitment, (ii) a sample license agreement, or (iii) one or more material licensing terms".

${ }^{60}$ See e.g., the OASIS Intellectual Property Rights Policy, approved in May 2, 2008, available at http://www.oasis-open.org/who/intellectualproperty.php (OASIS stands for Organization for the Advancement of Structured Information Standards; it is a SSO that develops and encourages the adoption of open standards in web-services and e-business).

${ }^{61}$ The size of the burden owing to higher royalty rates and its sharing between users and consumers are complex issues. The size depends on what part of investments are specific and on the price elasticity of demand for standard-compliant products, inter alia. The share depends on the pass-through rate, that is, the part of the increase in royalty that is passed on to consumers. This rate depends on the type of royalties (e.g., per unit royalty, fixed part), the nature of competition between manufacturers of standard-compliant products (e.g., perfect, monopolistic, oligopolistic), inter alia. For a primer, see Farrell et al. supra note 4 at 36-37.

${ }^{62}$ See Farrell et al. supra note 4 at 647: "Anticipation of hold-up encourages a range of inefficient forms of self-protection, such as postponing or minimizing investment, or ensuring that
} 
to mitigate their exposure to risk; they can postpone their decision about investments until the precise terms of licensing are known; or they may choose to make generic rather than specific investments, although the latter would perform more. In a nutshell, the threat of being held up results in allocative and productive inefficiencies that are detrimental to society, especially to consumers for whom standard-compliant products are produced in lower quantities, later and at a higher cost.

To sum up, the capability of the RAND commitment to safeguard against ex post opportunism of patent owners has likely been eroded. From now on parties involved in standard setting know that the meaning of RAND, especially regarding the level of royalty, is obscure. A few high profile cases have cast doubt on the binding force of the RAND promise. As a consequence, users are likely to fear a higher risk of being held up in the future and to respond to it by making less efficient investments. Some SSOs have proactively reformed their patent policy to address this new context. The section below attempts to analyse the welfare effects of the erosion of RAND promise credibility as well as some solutions that may restore it.

\section{A simple model for RAND licensing}

We develop in this section a simple theoretical model to illustrate the problem of RAND credibility and holdup. Our model is based on the following setting: A patent owner licenses an essential patent to a set of manufacturers who produce and sell a standard-compliant product.

Considering a single patent owner is sufficient because the problem of holdup

standards use only antique technology". For the first formal proof of inefficient investments resulting from the absence of effective safeguards against holdup, see Paul Grout, Investment and Wages in the Absence of Binding Contracts: A Nash Bargaining Approach, Econometrica, 52, 1984, 449- 460; see also Jean Tirole, Procurement and Renegotiation, Journal of Political Economy, 1986, 94, 235-259. 
can arise whatever the number of patent holders and patents. This simplification does not affect our results and presents the advantage of leaving aside another factor that, like holdup, can increasethe royalty the users of standards have to pay: the so-called multi-marginalization problem ${ }^{63}$. Briefly speaking, economic theory shows that without coordination owners of essential patents tend to set a too high royalty ${ }^{64}$. This problem can be solved by creating a patent pool in which are gathered all the essential patents of all patent owners. Our model, therefore, may describe either a single patent owner, or alternatively a manager of a pool that includes all the patents reading on the standard.

Rather than on holdup itself, we focus our analysis on the effect of the threat of being held-up. The manufacturers first incur a fixed cost of entry into the downstream market of the standard-compliant product, and then pay a per unit royalty on their production. A key feature of our model is that all manufacturers recoup their costs. In other words, manufacturers' surplus is always zero and they never incur a loss. Therefore, strictly speaking, no manufacturer is caught by holdup. holdup never happens but its economic effect is present in our model because the threat to be held-up results in a lower total investment made by manufacturers and, in turn, this sub-optimal investment results in a lower consumer surplus. In our model, those who are harmed by holdup are the consumers of standard-compliant products, not the manufacturers who pay the license and incur a fixed cost ${ }^{65}$. Our model works as if the holdup effect was entirely passed on to consumers ${ }^{66}$.

\footnotetext{
${ }^{63}$ The multimarginalization effects was first elaborated in 1838 by the French economist Antoine Augustin Cournot in Recherches sur les principes mathématiques de la théorie des richesses, 1974, Calmann-Levy, which shows that the merger between a monopolist of copper and a monopolist of zinc suppresses inefficient double monopoly margins and results in a lower price of brass for consumer and a higher joint profit for the monopolists.

${ }^{64}$ For an application of Cournot's approach on multimarginalization to complementary patents, see Mark A. Lemley and Carl Shapiro, Patent Holdup and Royalty Stacking, 85 Texas Law Review, 1991, 2007.

${ }^{65}$ The case where manufacturers are harmed because the patent owner breaches his ex ante commitment on the royalty he will ask is envisaged and elaborated in Annex.

${ }^{66}$ Note this is consistent with the idea that the pass-trough is high and manufacturers lack
} 
Let us define first the market for standard-compliant goods. We consider that $n$ symmetric manufacturers compete on this market. Assuming that their products are perfect substitutes, the inverse demand function is

$$
P=x-\sum_{i=1}^{n} q_{i}
$$

where $P$ and $x q_{i}$ denote respectively the market price and the valuation of the product by the consumers. The parameter $q_{i}$ reflects the production of manufacturer $i=1, \ldots n$, and $\sum_{i=1}^{n} q_{i}$ thus reflects the total production of all manufacturers.

We assume that the demand parameter $x$ is known by the manufacturers when they enter the market, but not by the patent owner. More precisely, $x$ is a random parameter for the patent owner, with distribution $F(x)$ on $[\underline{x}, \bar{x}]^{67}$. This assumption reflects the uncertainty surrounding the future success of the standard that is being developed. Indeed, standard-setting processes are subject to many sources of uncertainty, not only regarding the technical quality of the standard-to-come, but also the standard's potential success on the market, especially if it is competing with alternative standards ${ }^{68}$. Since we want to capture the uncertainty faced by the patent owner when he has to commit to licensing terms, we assume that the uncertainty holds until manufacturers have entered the market. Their entry indeed reveals the actual value of $x$ to the patent owner, who can then better adjust the level of royalty.

Before analyzing the licensing of the essential patent, we need to complete our presentation of the market for standard compliant products. Without loss of generality, we assume the unit production costs of manufacturers is zero. incentives to fight against holdup. See Farrell and al., supra note 4 .

${ }^{67}$ We assume that $F$ has the standard monotone hazard rate property: $f /[1-F]$ is increasing.

${ }^{68}$ See e.g., Stanley Besen and Joseph Farrell, Choosing How to Compete: Startegies and Tactics in Standardization, Journal of Economic Perspectives, 8: 117-131. 
Manufacturers pay the per unit royalty $R$ for using the technology standard. Given that $n-1$ other firms compete on the downstream market, manufacturer $i$ chooses its production $q_{i}$ so as to maximize its profit::

$$
q_{i}[P-R]=q_{i}\left[x-q_{i}-\sum_{j \neq i} q_{j}-R\right]
$$

Since all manufacturers behave the same way, each of them has the same individual production $q$ and profit $\pi_{M}$ at equilibrium. This profit can be expressed as follows:

$$
\pi_{M}=\left[\frac{x-R}{n+1}\right]^{2}
$$

As expected, it increases with the demand parameter $x$, and decreases with the royalty $\operatorname{cost} R$ and the number of competitors $n$.

There is a fixed cost $I$ of entry into the downstream market. This corresponds to the cost of implementing the standard, and determines the number of competitors that can be simultaneously in the market. More precisely, the free entry equilibrium is defined by the condition $\pi_{M}=I$, implying that the entry of one more competitor would entail a loss for all competitors. Using this condition and equation (1), we can derive the the total production $Q$ and the price $P$ of goods on the downstream market:

$$
\begin{gathered}
Q=n q=x-R-\sqrt{I} \\
P=\sqrt{I}+R
\end{gathered}
$$

Proof. See Appendix .

We can see from (3) that the price charged to consumers reflects the en- 
try cost $I$, plus the per unit royalty $R$. Hence the total production in (2) is decreasing in both $I$ and $R$.

In the next sections, we study successively two different scenarios of royalty setting. The first one features an effective RAND commitment: The licensor announces in advance he will ask for a reasonable royalty before manufacturers enter into the market; his commitment is binding and manufacturers know

precisely what level of royalty 'reasonable' means. In the second scenario, the RAND commitment is not credible and has therefore no effect on the manufacturers' entry decision. The patent owner commitment is just empty. This scenario is therefore similar to a situation wherein the patent owner does not make any announcement on the future royalty he will charge.

\subsection{Effective RAND}

This scenario offers an interesting benchmark because the threat to be held up here is nonexistent. As said above, we assume that the level of demand $x$ is a random parameter for the patent owner (with distribution $F(x)$ on $[x, x]$ ) whereas the manufacturers are not subject to this uncertainty. The timing of the game is therefore:

1. The licensor announces the reasonable royalty $R^{a}$ it will charge to downstream manufacturers. It does not know the exact level of demand at this moment.

2. Manufacturers enter the market taking into account the exact level of demand and the announced reasonable royalty.

Since entry takes place at the second stage, the manufacturers can anticipate the effect of the reasonable royalty and make their entry and production decisions accordingly. The total production is thus a function of $R$ as given by 
(2), and the licensor solves

$$
\begin{aligned}
\max _{R} \widetilde{\pi}_{L}^{a} \equiv R \int_{\underline{x}}^{\bar{x}} Q(R) f(x) d x \\
\text { where } \\
Q(R)=x-R-\sqrt{I}
\end{aligned}
$$

The optimal royalty resulting from this program is

$$
R^{a}=\frac{E(x)-\sqrt{I}}{2}
$$

The reasonable royalty announced by the licensor depends on the expected level of demand $E(x)$, minus a term reflecting the entry cost $I$ of manufacturers. If entry costs are high, the patent owner would rather commit on a lower royalty in order to benefit of a larger number of entrants, and hence a higher level of production and sales. Doing so is indeed profitable for the patent owner because the loss in royalty revenue per unit of product is offset by a larger expected quantity of products on which royalties will be paid.

Recall that the royalty is fixed once for all before the entry of manufacturers. Observing this announced royalty and the actual level of demand $x$, manufacturers will enter until the profit of entry becomes nil. At this point the market price of standard compliant products is $P^{a}=R^{a}+\sqrt{I}$. The actual level of demand $x$ does not affect this price, but given $R^{a}$, it determines the actual number $n^{a}$ of manufacturers who can enter the market:

$$
n^{a}=\frac{x+[x-E(x)]-\sqrt{I}}{2 \sqrt{I}}
$$

Consequently, it determines the total production of standard compliant goods $Q^{a}=\sqrt{I} n^{a}$. From equation (5) we can see that the number of manufac- 
turers on the market depends not only on the actual, but also on the discrepancy between the actual and expected levels of demand. There is more entry if expected demand happens to be lower than the actual one, for then the licensor charges a lower royalty than what it would have done with full information.

\subsection{Broken RAND}

Let us study now the scenario wherein the patent owner sets his royalty after manufacturers entered into the market for standard-compliant products. As mentioned above, this scenario can be interpreted in two ways. Firstly, it corresponds to the case where the patent owner gives no assurance on his future licensing terms. Secondly, the scenario is interpreted as what happens when the RAND promise is not credible. Here, the patent owner announces in advance the licensing terms but his commitment is not taken into account by users. For instance, users do not know what a reasonable royalty means or they have good reason to think that the promise is unenforceable. For both interpretations, manufacturers know the risk of holdup is maximal.

The timing of the game is now the following:

1. Manufacturers observe the actual level of demand and enter the market.

2. The licensor observes the actual level of demand and number of manufacturers, and sets a royalty $R^{p}$.

We solve the game backwards and therefore study first the licensor's licensing strategy when the number $n$ of manufacturers is given. The licensor maximizes its total royalty revenue: 


$$
\begin{aligned}
\max _{R} \pi_{L}^{p}(R) \equiv & n R q(R, n) \\
& \text { where } \\
q(R, n)= & \frac{x-R}{n+1}
\end{aligned}
$$

The optimal royalty resulting from this program is

$$
R^{p}(x)=\frac{x}{2}
$$

Obviously this ex post royalty does not depend anymore on the expected level of demand $E(x)$, but rather on the actual level $x$. Moreover, the licensor does not take into account the entry cost of manufacturers, as was the case in (4). Indeed, since royalty setting takes place once manufacturers have entered the market, the licensor can no longer use the royalty to attract more manufacturers on the market in order to boost production and sales.

Manufacturers are rational and can therefore anticipate this level of royalty when they enter the market. Given a demand level $x$ and the corresponding royalty $R^{p}(x)$, there is room for $n^{p}$ manufacturers on the market, where

$$
n^{p}=\frac{x-2 \sqrt{I}}{2 \sqrt{I}},
$$

and the product price charged to consumers at free entry equilibrium is $P^{p}=R^{p}+\sqrt{I}$. Note that we have $P^{p}>P^{a}$ (and $n^{p}<n^{a}$ ) if the following condition is verified:

$$
R^{p}>R^{a} \Leftrightarrow \sqrt{I}>E(x)-x
$$

Assuming that the actual level of demand meets the expectation (e.g., $x=$ 
$E(x))$, it is clear that the broken RAND scenario would entail a higher royalty than in the case of the effective the RAND scenario: $R^{p}>R^{a}$. The reason is that by setting the royalty ex post, the patent owner neglects the fact that a lower royalty would attract more manufacturers in the market, and thus charges an excessive royalty. In fact, $R^{p}<R^{a}$ is possible only in the particular case where the actual level of demand $x$ happens to be much lower than expected (so that the RAND royalty was overshot) while the entry cost $I$ is relative low (so that entry is not substantially affected by the royalty level).

This result can be generalized. Considering both scenarios from an ex ante standpoint (e.g., while the level of demand is still uncertain), we can show easily that $E\left(R^{p}\right)>R^{a}$ always holds, such that in turn $E\left(P^{p}\right)>P^{a}$ and $E\left(n^{p}\right)<E\left(n^{a}\right)$. In other terms, a broken RAND scenario entails on average a higher royalty, and thus less entry and higher prices charged to consumers for standard-compliant products.

Proposition 1 On average, effective RAND dominates broken RAND in terms of consumer welfare.

\subsection{Effective RAND can be beneficial to the patent owner}

To complete the comparison, let us consider now the patent owner's profits in the broken RAND and effective RAND scenarios. For sake of clarity, we proceed in two steps. We consider first the licensing profits for a given value of $x$, before comparing the expected profits from an ex ante standpoint, that is, when the value of $x$ is still uncertain.

Computing the licensing profit of the patent owner for a given $x$ yields the following results, respectively got in the effective and broken RAND scenarios: 


$$
\begin{aligned}
\pi_{L}^{a}(x) & =\frac{1}{4}[E(x)-\sqrt{I}][2 x-E(x)-\sqrt{I}] \\
\pi_{L}^{p}(x) & =\frac{x}{4}[x-2 \sqrt{I}]
\end{aligned}
$$

These expressions are difficult to interpret directly, but it can be shown easily that $\pi_{L}^{a}>\pi_{L}^{p}$ if:

$$
I>[x-E(x)]^{2}
$$

Hence the effective RAND scenario entails higher ex post profits if, given the entry cost $I$, the actual level of demand $x$ is not too far from its expected level $E(x)$. In other words, the effective RAND scenario generates larger profits provided the ex ante commitment does not induce an excessive over-or undershooting of the royalty $R^{a}$. This highlights the risk taken by the licensor in making an ex ante commitment on $R^{a 69}$. Note, moreover, that $\pi_{L}^{a}>\pi_{L}^{p}$ holds only if the loss associated with a wrong anticipation of $x$ exceeds a threshold depending on the entry cost $I$. The parameter $I$ reflects here the positive effect of the effective RAND commitment on entry, and therefore is as a way to mitigate holdup. It indicates that the dominance of the RAND scenario is all the more likely as entry is costly-and thus sensitive to the royalty level. Note also that depending on whether $x>E(x)$ or $x<E(x)$, a wrong anticipation by the licensor will also either benefit or be detrimental to consumers.

We now turn to the second step in comparing profits. Denoting, respectively, $\widetilde{\pi}_{L}^{a}$ and $\widetilde{\pi}_{L}^{p}$, the expected profits of the licensor in the effective and broken RAND scenarios, we have:

\footnotetext{
${ }^{69}$ Note that depending on whether $x<E(x)$ or $x>E(x)$, a wrong anticipation by the licensor will also either benefit or be detrimental to consumers.
} 


$$
\begin{aligned}
& \widetilde{\pi}_{L}^{a}=\int_{\underline{x}}^{\bar{x}} \pi_{L}^{a}(x) f(x) d x=\frac{1}{4}[E(x)-\sqrt{I}]^{2} \\
& \widetilde{\pi}_{L}^{p}=\int_{\underline{x}}^{\bar{x}} \pi_{L}^{p}(x) f(x) d x=\frac{1}{4}\left[E\left(x^{2}\right)-2 \sqrt{I} E(x)\right]
\end{aligned}
$$

Again, it is difficult to interpret these expressions directly. Yet comparing them quickly shows that $\widetilde{\pi}_{L}^{a}>\widetilde{\pi}_{L}^{p}$ if

$$
I>\operatorname{Var}(x)
$$

We can thus derive the following Proposition.

Proposition 2 The licensor benefits from an effective RAND scenario if the cost of entry is high and/or the uncertainty on demand is low.

Proof. See Appendix.

Proposition 2 generalizes the comparison of profits. It shows that when the cost of entry is high the effective RAND scenario is the most profitable situation for the licensor, for providing manufacturers with a guarantee on royalties then ensures a maximal entry into the product market. The downside is, however, the risk taken by the licensor in anticipating the level of demand. The licensor would always benefit from the effective RAND scenario if the demand were not uncertain (e.g., $\operatorname{Var}(x)=0$ ). By contrast, uncertain demand generates a risk of overshooting or undershooting when committing on a royalty, thereby inducing a loss (by stiffling entry with a too high royalty in the first case, or missing easy profits by charging a too low royalty in the second case) for the licensor. In this context, the licensor's interest in RAND as an effective mechanism against 
holdup is contingent-it ultimately depends on the extent of demand uncertainty and fixed costs for manufacturers.

\section{$5 \quad$ Testing new SSOs IP policies}

In this section we assume that the RAND regime is broken. Manufacturers do not believe that the patent owner will comply with his comitment to charge a reasonable royalty or are unable to guess what 'reasonable' means in the mind of the patent owner. In both cases, they consequently behave as if the patent owner had said nothing regarding the future royalty, and consumers will be harmed. As demonstrated in the previous section, this situation is beneficial or detrimental to the patent owner depending on the level of demand uncertainty and fixed costs. Patent owners have therefore an ambivalent interest in the restoring of RAND regime. Knowing that nowadays most members of SSOs

own patents, SSOs may therefore lack the support of their constituency in such a restoration. They need to imagine new IP policies that better align the patent owners' interests and the consumers' interests. Is this the case of the policy adopted by the two SSOs VITA and IEEE, in which members commit on a royalty cap rather than on a reasonable royalty (see section 3)? We use our model to answer this question of adopting a new approach. Instead of assessing, as in the previous section, the consequences of an effective or a broken RAND regime, we use our model to predict the choice of the patent owner between different strategies, namely giving no assurance, announcing the exact royalty, or announcing a royalty cap.

The outcome of the first two strategies regarding the patent owner's has already been exposed. When the patent owner provides manufacturers with no assurance on the future royalty, he will ex post charge $R^{p}=x / 2$ and his profit is given by equation (10) because the absence of ex ante announcement is 
strictly equivalent to the broken RAND scenario. Similarly, the announcement of the exact royalty is strictly equivalent to the effective RAND scenario because we assumed in this scenario that manufacturers understand exactly what constitutes a reasonable royalty and they believe in the patent owner's promise. Therefore, the royalty is $R^{a}=(E(x)-\sqrt{I}) / 2$ and the patent owner's profit is given by (9).

Let us examine now the profit of the patent owner in the case of a royalty cap.

\subsection{A new policy option: royalty cap}

In the case of a royalty cap, the patent owner has the possibility to adjust his royalty after the entry of manufacturers, in function of the actual value of the market, $x$. His commitment simply requires that the ex post royalties be not fixed above the ex ante announced cap, but the owner remains free to fix any royalty below the cap if appropriate. Transposed in our analytical setting, the timing of this new policy is the following:

1. The licensor credibly commits on a royalty cap $R^{c}$ while demand for the standard is still uncertain.

2. Manufacturers observe the actual level of demand and, given the announced cap, enter the market.

3. Given the actual level of demand and number of manufacturers, the licensor sets a royalty equal to, or lower than, the announced cap.

As in the previous section, we solve this game backwards, starting thus with the third stage. Observe first that in absence of commitment the licensor would set an ex post royalty $R^{p}$ in function of the observed demand $x$, as in the noassurance strategy. Given the cap $R^{c}$ announced at stage 1, the licensor would 
thus rather revise the royalty downwards if the ex post royalty $R^{p}<R^{c}$. If $R^{p}>R^{c}$, the licensor would rather charge an ex post royalty above the cap, but he cannot because he is bound by his commitment. Recall also that the ex post royalty cap is increasing in the oberved level of demand $x$. Hence we can expect the licensor to price below the cap if $x$ happens to be lower than expected, and to be bound by the cap otherwise.

Let $\widehat{x}\left(R^{c}\right)$ denote the demand level at which the licensor is indifferent between revising the royalty or not. This demand level is defined by $R^{p}(\widehat{x})=R^{c}$, that is:

$$
\frac{\widehat{x}}{2}=R^{c} \Leftrightarrow \widehat{x}\left(R^{c}\right)=2 R^{c}
$$

For any $x<\widehat{x}\left(R^{c}\right)$, the licensor will revise the royalty, while he will stick to $R^{c}$ when $x \geq \widehat{x}\left(R^{c}\right)$.

The threshold $\widehat{x}\left(R^{c}\right)$ also commands the manufacturers' entry decision at stage 2. If manufacturers observe that $x>\widehat{x}\left(R^{c}\right)$, they anticipate a royalty $R^{c}$ and make their entry decision accordingly. The cap thus works as an ex ante commitment on a precise royalty $R^{c}$. If, on the other hand, $x<\widehat{x}\left(R^{c}\right)$, manufacturers anticipate that the royalty will be fixed ex post, similar to a no assurance strategy, and make their entry decision accordingly. The royalty cap strategy is thus a mix of the no-assurance and the exact royalty strategies. The lower the cap $R^{c}$, the lower the demand threshold $\widehat{x}\left(R^{c}\right)$ above which the cap is binding, and thus the more likely the commitment is to have a positive effect on manufacturers' entry.

This effect is critical in the licensor's choice of the cap announced at stage 1. His expected profit at stage 1 can be expressed as follows: 


$$
\tilde{\pi}_{L}^{c}\left(R^{c}\right)=\int_{\underline{x}}^{\widehat{x}\left(R^{c}\right)} \pi_{L}^{p}\left(R^{p}(x)\right) f(x) d x+\int_{\widehat{x}\left(R^{c}\right)}^{\bar{x}} \pi_{L}^{a}\left(R^{c}\right) f(x) d x
$$

We can see that the profit of the licensor corresponds respectively to the no-assurance strategy if $x<\widehat{x}\left(R^{c}\right)$, and to the exact royalty scenario (with a royalty equal to $R^{c}$ ) if $x \geq \widehat{x}\left(R^{c}\right)$. Compared to the absence of commitment, setting a low cap is thus a way to foster entry when $x>\widehat{x}\left(R^{c}\right)$, but makes it impossible to adjust the royalty upwards. Put differently, the cap works as a precise royalty commitment holding only when the demand $x$ happens to be strong. The licensor will then choose the cap as follows.

Lemma 3 The licensor's decision in the royalty cap strategy is the following:

- If $I<(E(x)-\underline{x})^{2}$, the licensor defines a royalty cap $\left.R^{c} \in\right] R^{a}, \bar{x} / 2[$, where

$$
R^{c}=\frac{E\left(x \mid x \geq \widehat{x}\left(R^{c}\right)\right)-\sqrt{I}}{2}
$$

- If $I \geq(E(x)-\underline{x})^{2}$, the licensor sets

$$
R^{c}=\frac{E(x)-\sqrt{I}}{2}=R^{a}
$$

and never revises the royalty ex post.

Proof. See Appendix.

Two cases are possible, depending mainly on the level of the entry cost I. When $I<(E(x)-\underline{x})^{2}$, the licensor sets a royalty cap that allows him to revise the royalty when the actual level of demand happens to be lower than expected. Note that the optimal cap is decreasing in the entry cost $I$, until 
$I=(E(x)-\underline{x})^{2}$. At this point it can be shown that the cap is exactly equal to the exact ex ante royalty:

$$
R^{c}=\frac{x}{2}=\frac{E(x)-\sqrt{I}}{2}=R^{a}
$$

Since $\underline{x} / 2$ is the lowest possible royalty charged in the case of no-assurance strategy, it follows that the licensor will never revise its royalty ex post. Consequently the cap works here exactly as an exact royalty strategy. The same logic prevails when $I<(E(x)-\underline{x})^{2}$. The cap $R^{c}$ then remains equal to the RAND royalty $R^{a}$. It is thus still decreasing in $I$ and makes it impossible to adjust the royalty ex post.

Finally, the royalty cap strategy always makes it possible for the licensor to replicate the no-assurance strategy, simply by setting a very high cap $R^{c} \geq \bar{x}$ that would never be applied ex post. Lemma 3, however, shows us that the licensor will never choose such a high cap. Hence, by revealed preferences, this implies that the licensor can always improve upon the no-assurance strategy by using a royalty cap. Moreover, the cap implies an ex post royalty equal or lower to the no-assurance royalty, depending on whether the cap is applied or not. As a consequence, the expected royalty is always lower under the royalty cap than without assurance. This implies in turn that the expected price of standard compliant products is always lower with a royalty cap.

Proposition 4 In expectation, the royalty cap always dominates the no-assurance strategy in terms of both licensing profits and prices of standard compliant products.

This result provides strong support for the licensing policy as designed by VITA. Requiring patent owners to commit on a royalty cap is indeed profitable for all stakeholders of the standard setting process, and therefore strongly im- 
proves the situation vis-à-vis the broken RAND regime. This contrasts with the RAND commitment which, as we have seen, is profitable to the licensor only in some cases, namely if entry costs are high and/or uncertainty is mild.

\subsection{Royalty cap versus RAND commitment}

Nevertheless, we cannot yet definitively conclude on the superiority of the cap policy. For this we would need to show that a commitment on a royalty cap is always a better alternative to the exact royalty commitment.

The question may actually be addressed in different ways, depending on whose interests are taken into account. Recall that competition drives manufacturers' profits to zero in all strategies. Hence the outcome of licensing mainly affects the licensor and the consumers of standard-compliant goods. Since patents are supposed to reward innovation, the licensor's profits should prevail. From that perspective the best type of commitment is thus the one the licensor would opt for. It is nevertheless interesting to analyze how this affects the welfare of consumers. We have seen, for instance, that in some cases the exact royalty strategy benefits to both consumers and the licensor as compared to the no-assurance strategy.

Let us compare how each strategy affects the price of standard-compliant products. On the one hand, the cap is either equal to or larger than the precise royalty. In the cap strategy, we can thus expect royalties, and therefore product prices, to be higher when ex post demand is large such that the royalty is set at the cap. On the other hand, the cap provides flexibilty for the licensor to set a lower royalty ex post, while the ex ante exact royalty is fixed once for all. Hence we expect royalties and the price of standard-compliant products to be lower under a cap when ex post demand is low. Whether the cap or the exact royalty induces lower prices in expectation depends on the balance 
between these two opposite effects. Simple calculations show that both effects in fact strictly compensate each other:

Proposition 5 In expectation, the ex post royalties and the product prices are equal under the royaty cap strategy and the exact royalty strategy.

Proof. See Appendix.

This result is important, for it shows that the choice of the patent owner to commit in announcing in advance an exact royalty or a royalty cap is neutral from the standpoint of consumers. Hence there is no reason to mandate one particular type of commitment in the name of consumers. In contrast, it makes full sense to let the licensor decide on the type of commitment that maximzes its profits. Allowing the licensor to choose freely between the two strategies is the best way to maximize the reward associated with patents - and thus the incentive to innovate.

Let us now compare how each strategy affects the licensors' profits. We can derive the following results from our model:

Lemma 6 The comparison of the licensor's expected profits under the cap and RAND commitment yieds the following outcomes:

1. If $I<\operatorname{Var}(x)$, we have $\tilde{\pi}_{L}^{c}>\widetilde{\pi}_{L}^{a}$,

2. If $\operatorname{Var}(x) \leq I<(E(x)-\underline{x})^{2}$, whether $\widetilde{\pi}_{L}^{c}>\widetilde{\pi}_{L}^{a}$ is ambiguous,

3. If $I \geq(E(x)-\underline{x})^{2}$, we have $\widetilde{\pi}_{L}^{a}=\widetilde{\pi}_{L}^{c}$.

We obtain a clear-cut result in the two exetreme cases. Given a distribution $F(x)$, the royalty cap is more profitabe than the exact royalty when the entry cost $I$ is low (case 1). In that case, entry limitation is indeed mild in absence 
of commitment, so that a licensor would rather give no assurance. Committing on a cap then appears as a more attractive alternative, for it allows the licensor to keep as much flexibility as desired to adjust royalties ex post. The result is clear as well when the entry cost is large (case 3). In that case we have seen that the licensor using a cap never adjusts the royalty ex post, and that the cap is in fact equal to the precise royalty strategy. Both types of commitments are thus perfectly equivalent from the standpoint of the licensor.

The intermediate case where $\operatorname{Var}(x) \leq I<(E(x)-\underline{x})^{2}$ (case 2) is ambiguous. The outcome of the comparison indeed depends on the distribution $F(x)$, so that it is impossible to derive a clear-cut conclusion. Depending on the cases, the licensor's best strategy will be either the cap or a precise royalty. Given this last result, we can draw the following conclusion:

Proposition 7 Allowing the licensor to opt for a contractual commitment of any type is efficient in that:

- The licensor will always opt either for a cap or for an exact royalty commitment

- Consumers will benefit of a lower expected price than when the RAND regime is broken, this expected price being the same with a cap or an exact royalty commitment

- The commitment chosen by the licensor is the one that maximzes his expected licensing profit, and thus his incentives to innovate.

Since the licensor always prefers to make a contractual commitment to the broken RAND regime, the outcome of a free choice left to the patent owner is always beneficial to consumers, in a way that does not depend on how the choice is exercized. The interests of the licensor and consumers converge since all can benefit from letting the licensor freely choose the contractual commitment. 
This result has important policy implications. While Proposition 4 established that the royalty cap is an attractive policy option that dominates the broken RAND regime from the standpoint of both licensor and consumers, Proposition 7 in turn shows that requiring a cap alone may still not be the best policy option. There can indeed cases in which the licensor would rather announce in advance the exact royalty he will charge in the future without deteriorating the welfare of consumers. From that perspective, offering a menu of commitments-cap or exact royalty-is even a better policy. The policy of IEEESA, as it provides a menu of licensing commitments, seems thus even better than the cap commitment proposed in the VITA policy.

\section{Conclusion}

Standard-setting activities have evolved dramatically over the past decade. As standards gained importance in the IT industries, SSOs have involved an increasing number of participants, and the IP content of standard specifications follows a similar trend. This evolution has called into question the traditional practices of SSOs, especially as regards the licensing of essential patents. In the trail of recent antitrust cases, doubts have been cast in particular on the effectiveness of the current SSO IP policies requiring that essential patent owners commit to licensing their IP on RAND terms, the latter commitments being now perceived as too vague. Against this background, the purpose of this paper was twofold. We first highlighted the rationale of the old RAND regime, as well as its effects when it becomes ineffective to mitigate the holdup problem. We then discussed the advantages of requiring more precise commitments. In addition to a contractually binding ex ante commitment on the exact royalty, we analyzed and compared the effects of two new IP policies currently experimented in some SSO: requiring that patent owners commit on a royalty cap as experimented by 
VITA, and allowing patent owners to choose freely whether to commit on a cap or an exact royalty, as experimented with IEEE-SA.

Using a simple licensing model, we have shown that licensing commitments made before manufacturers sink fixed costs in standard adoption induce lower prices for standard compliant products. From this standpoint it is even in the interest of the licensor to induce more entry by committing on charging low royalties to manufacturers. Making such ex ante commitments is, however, also a risky strategy, for licensors have to commit while the commercial success of the standard is still uncertain, thereby loosing the possibility to fine tune their licensing policy ex post. Eventually, whether patent owners are willing to commit thus depends on the balance between uncertainty and entry promotion.

Against this background, ongoing litigations and the fear of holdup they may generate may actually be sufficient to break confidence, notwithstanding their judicial outcome. In a nutshell, there are thus good reasons to think that the RAND regime may have worked, but is now broken.

Building on these premises, we have explored the interests of reforming SSO IP policies by requiring contractually binding commitments from patent owners. Using our model, we derived several policy-relevant results concerning royalty cap, exact royalty commitment, and a menu combining both.

Our analysis implies that restoring the RAND regime would actually be welcomed by patent owners when manufacturers incur high entry costs, while ex ante uncertainty on the standard's commercial success is mild. Conversely, they would not support the restoring if these conditions do not hold, because it will reduce licensing profits and incentives to innovate.

Against this backdrop, a commitment on a royalty cap is a very attractive option. A royalty cap provides an interesting compromise between uncertainty and investments. It guarantees manufacturers against prohibitive ex post royalties, 
while preserving some possibilities for the licensor to adjust royalty downwards when the commercial success of the standard is lower than expected. Compared with a no-assurance policy, a royalty cap policy is thus systematically beneficial to both licensors and consumers. Contrary to what happens with the exact ex ante royalty, such benefits hold true true whatever the entry costs of manufacturers and the degree of uncertainty on the standard's market success. In this respect, the IP policy experienced by VITA is an efficient one.

We also show that a policy of menus-letting the licensor choose freely between committing on a cap, on a exact royalty and giving no assurance-is the more efficient IP policies for SSOs. Since the licensor would always choose either a cap or an exact royalty, consumers would also benefit from a lower price.

In turn, the free choice would allow the licensor to maximize profit, thereby maximizing incentives to innovate in the standard development. Although the VITA IP policy is an attractive one, the policy of IEEE-SA is even preferable.

\section{Appendix}

\section{Price and quantity on the product market at free entry equilibrium}

At symmetric equilibrium, the individual production $q$ and profit $\pi_{M}$ of a manufacturer are respectively

$$
\begin{aligned}
& q(R, n)=\frac{x-R}{n+1} \\
& \pi_{M}(R)=q(R)^{2}
\end{aligned}
$$

There is a fixed cost $I$ of entry into the downstream market. This corresponds 
to the cost of implementing the standard. Given a royalty level $R$, firms enter into the market until the entry profit is zero, e.g., $\pi(n)=I$. At free entry equilibrium, the number of manufacturers is thus given by

$$
n(R)=\frac{x-R-\sqrt{I}}{\sqrt{I}}
$$

Observe that at free entry equilibrium the individual production is $q=\sqrt{I}$ whatever the level of royalty $R$. From $n$ and $q$ we can derive the total production $Q$ and the price $P$ of goods on the downstream market:

$$
\begin{gathered}
Q(R)=n(R) q(R, n(R))=x-R-\sqrt{I} \\
P(R)=\sqrt{I}+R
\end{gathered}
$$

\section{Proof of Lemma 3}

We demonstrate first how we obtain the first order condition. Recall that the expected profit of the licensor writes:

$$
\tilde{\pi}_{L}^{c}(R)=\Phi+\Psi
$$

where

$$
\left\{\begin{array}{c}
\Phi=\int_{\underline{x}}^{\widehat{x}(R)} \pi_{L}^{p}\left(R^{p}(x)\right) f(x) d x \\
\Psi=\int_{\widehat{x}(R)}^{\bar{x}} \pi_{L}^{a}(R) f(x) d x
\end{array}\right.
$$

The licensor maximizes this profit with respect to $R \in[\underline{x} / 2, \bar{x} / 2]$. We express successively the derivative of the two terms of the expression on the right hand side. Consider the first $\Phi$. Its full expression is: 


$$
\Phi=\int_{\underline{x}}^{\widehat{x}(R)} \frac{x}{4}[x-2 \sqrt{I}] f(x) d x
$$

Using the expression of $\widehat{x}(R)=2 R$ from (11) its derivative is:

$$
\begin{aligned}
\frac{d \Phi}{d R} & =\frac{\partial \Phi}{\partial \widehat{x}} \frac{\partial \widehat{x}}{\partial R} \\
& =\frac{\widehat{x}}{2}[\widehat{x}-2 \sqrt{I}] f(\widehat{x})
\end{aligned}
$$

and finally

$$
\frac{d \Phi}{d R}=2 R[R-\sqrt{I}] f(2 R)
$$

Consider now $\Psi$. Its full expression is:

$$
\Psi=\int_{\widehat{x}(R)}^{\bar{x}} R[x-R-\sqrt{I}] f(x) d x
$$

and it can be reformulated into

$$
\Psi=-R \int_{\bar{x}}^{\widehat{x}(R)} x f(x) d x-R[R+\sqrt{I}][1-F(\widehat{x}(R))]
$$

Its derivative is:

$$
\begin{aligned}
\frac{d \Psi}{d R}= & \frac{\partial \Psi}{\partial \widehat{x}} \frac{\partial \widehat{x}}{\partial R}+\frac{\partial \Psi}{\partial R} \\
= & 2 R f(\widehat{x}(R))[-\widehat{x}(R)+R+\sqrt{I}] \\
& -\int_{\bar{x}}^{R} x f(x) d x-[2 R+\sqrt{I}][1-F(\widehat{x}(R))]
\end{aligned}
$$


Using the expression of $\widehat{x}(R)=2 R$ from (11) we obtain:

$$
\begin{aligned}
\frac{d \Psi}{d R}= & \frac{2 R}{\alpha}[-R+(2-\alpha) \sqrt{I}] f(2 R) \\
& -\frac{1}{\alpha} \int_{\bar{x}}^{2 R} x f(x) d x-\frac{1}{\alpha}[c+2 R+(2-\alpha) \sqrt{I}][1-F(2 R)]
\end{aligned}
$$

Summing (13) and (14) gives:

$$
\begin{aligned}
\frac{\partial \widetilde{\pi}_{L}^{c}}{\partial R}= & 2 R[R-\sqrt{I}] f(2 R)+\frac{2 R}{\alpha} f(2 R)[-R+\sqrt{I}] \\
& -\int_{\bar{x}}^{2 R} x f(x) d x-[2 R+\sqrt{I}][1-F(2 R)]
\end{aligned}
$$

The sum of the first two terms is zero. Moreover, observing that

$$
\frac{\int_{2 R}^{\bar{x}} x f(x) d x}{1-F(2 R)}=E(x \mid x \geq \widehat{x}(R))
$$

we can rewrite:

$$
\begin{gathered}
\frac{\partial \widetilde{\pi}_{L}^{c}}{\partial R}=[1-F(2 R)]\{E(x \mid x \geq \widehat{x}(R))-2 R-\sqrt{I}\} \\
=[1-F(\widehat{x})]\{E(x \mid x \geq \widehat{x})-\widehat{x}-\sqrt{I}\}
\end{gathered}
$$

Since $F(\widehat{x}(R)) \leq 1$, the sign of $\partial \widetilde{\pi}_{L}^{c} / \partial R$ depends on the term in arrows. Let

$$
L(y) \equiv E(x \mid x \geq y)-y, \quad y \in[\underline{x}, \bar{x}]
$$

It can be checked easily that $L(\bar{x})=\bar{x}-\bar{x}=0$ while $L(\underline{x})=E(x)-\underline{x}>$ 
0. Assuming that $F$ has the standard monotone hazard rate property, e.g., $f /[1-F]$ is increasing, in turn implies that $E(x \mid x \geq y)$ grows with $y$ at a rate lower than 1 . It follows that $L(y)$ is strictly decreasing in $y$ :

$$
L^{\prime}(y)=\frac{f(y)}{1-F(y)} L(y)-1<0
$$

Since $L(y)$ is strictly decreasing in $y$ from $L(\underline{x})=E(x)-\underline{x}$ to $L(\bar{x})=$ $\bar{x}-\bar{x}=0$, it follows that the terms in arrows in (15) is decreasing in $\widehat{x}$. Given that

$$
E(x \mid x \geq \bar{x})-\bar{x}-\sqrt{I}=-\sqrt{I}<0
$$

there are two possibilities depending on $E(x)-\underline{x}$.

If $E(x)-\underline{x}>\sqrt{I}$, equation (16) has an interior solution $\widehat{x} \in[\underline{x}, \bar{x}]$, where:

$$
R^{c}=\frac{1}{2}\left[E\left(x \mid x \geq \widehat{x}\left(R^{c}\right)\right)-\sqrt{I}\right]
$$

If $E(x)-\underline{x} \leq \sqrt{I}$, equation (16) has no interior solution on $[\underline{x}, \bar{x}]$. We have then $\partial \widetilde{\pi}_{L}^{c} / \partial R<0$ for all $R \in[\underline{x} / 2, \bar{x} / 2]$. Hence the optimal royalty cap on $[\underline{x} / 2, \bar{x} / 2]$ is $R^{c}=\underline{x} / 2$. Note that this cap is equivalent to an ex ante commitment on a royalty since the royalty is never revised ex post.

Moreover, observe that when $E(x)-\underline{x}=\sqrt{I}$ we have:

$$
\left.R^{c}\right|_{E(x)-\underline{x}=\sqrt{I}}=\underline{x} / 2=\frac{E(x)-\sqrt{I}}{2}=R^{a}
$$

Hence for $E(x)-\underline{x}=\sqrt{I}$ the cap is exactly equivalent to an ex ante RAND commitment. So far we have assumed that the cap should belong to the interval $[\underline{x} / 2, \bar{x} / 2]$, and we have seen that the corner solution $R^{c}=\underline{x} / 2$ emerges when 
$E(x)-\underline{x} \leq \sqrt{I}$. In that case there is no reason to exclude that the licensor could also commit on a cap in the interval $[0, \underline{x} / 2]$. Since this type of cap would never entail an ex post revision, it is exactly similar to an ex ante commitment $R^{a} \in[0, \underline{x} / 2]$. Since we know that $R^{c}=R^{a}=\underline{x} / 2$ when $E(x)-\underline{x}=\sqrt{I}$, and that $R^{a}<\underline{x} / 2$ is more profitable for the licensor when $E(x)-\underline{x}<\sqrt{I}$, it follows that the licensor sets the royalty cap $R^{c}=R^{a}$ according to the RAND scenario when $E(x)-\underline{x}<\sqrt{I}$.

\section{Proof of Proposition 5}

We compare here the expected prices of standard-compliant products under the cap and RAND commitment. Since in any case we have

$$
p=\sqrt{I}+R
$$

it is sufficient for us to compare the expected royalties under both scenarios.

The royalty cap replicates the ex post royalty $R^{p}(x)=(x-c) / 2$ when $x<\widehat{x}$. If $x \geq \widehat{x}$, the royalty is constant and equal to $R^{c}$. The expected price charged to consumers when the licensor announces a royalty cap is thus:

$$
E\left(P^{c}\right)=\int_{\underline{x}}^{\widehat{x}}\left[c+\sqrt{I}+R^{p}(x)\right] f(x) d x+\left[c+\sqrt{I}+R^{c}\right][1-F(\widehat{x})]
$$

Recall that the expected price under RAND commitment is

$$
E\left(P^{a}\right)=\left[c+\sqrt{I}+R^{a}\right] \int_{\underline{x}}^{\bar{x}} f(x) d x
$$

Hence we have: 


$$
E\left(P^{c}\right)-E\left(P^{a}\right)=\int_{\underline{x}}^{\widehat{x}}\left[R^{p}(x)-R^{a}\right] f(x) d x-\left[R^{a}-R^{c}\right][1-F(\widehat{x})]
$$

Using the expressions of $R^{p}(x), R^{c}$ and $R^{a}$, this rewrites:

$$
\begin{aligned}
E\left(P^{c}\right)-E\left(P^{a}\right) & =\frac{1}{2} \int_{\underline{x}}^{\widehat{x}}[x-E(x)] f(x) d x-\left[\frac{E(x)-E(x \backslash x>\widehat{x})}{2}\right][1-F(\widehat{x})] \\
& =\frac{1}{2}\{[E(x \backslash x>\widehat{x})-E(x)] F(\widehat{x})-[E(x)-E(x \backslash x>\widehat{x})][1-F(\widehat{x})]\} \\
& =\frac{1}{2}\{F(\widehat{x}) E(x \backslash x>\widehat{x})+[1-F(\widehat{x})] E(x \backslash x>\widehat{x})-E(x)\} \\
& =0
\end{aligned}
$$

\section{Proof of Lemma 6}

Note first that when $[E(x)-\underline{x}]^{2} \leq I$, we have $R^{c}=R^{a}$. Moreover, we know that the royalty cap is always more profitable than the broken RAND scenario for the licensor. Since we also know that the licensors would opt for the broken RAND rather than exact royalty if $\operatorname{Var}(x)>I$, it follows that the royalty cap strategy also dominates the exact royalty strategy if $\operatorname{Var}(x)>I$. As a consequence, $\operatorname{Var}(x)>I$ is not compatible with $[E(x)-\underline{x}]^{2} \leq I$, which implies that $\operatorname{Var}(x)<[E(x)-\underline{x}]^{2}$.

Now the comparison is still ambiguous when $\operatorname{Var}(x)<I<[E(x)-\underline{x}]^{2}$. From (9), the expected exact royalty profit is

$$
\widetilde{\pi}_{L}^{a}\left(R^{a}\right)=\frac{1}{4}[E(x)-\sqrt{I}]^{2}
$$

Computing in turn the expected profit under royalty cap gives: 


$$
\tilde{\pi}_{L}^{c}=\int_{\underline{x}}^{\widehat{x}} \frac{x}{4}[x-2 \sqrt{I}] f(x) d x+R^{c} \int_{\widehat{x}}^{\bar{x}} x f(x) d x-R^{c}\left[R^{c}+\sqrt{I}\right][1-F(\widehat{x})]
$$

Using the expression $R^{c}$ in (17), we can factorize the last two terms on the right-hand side to obtain:

$$
\widetilde{\pi}_{L}^{c}=\int_{\underline{x}}^{\widehat{x}} \frac{x}{4}[x-2 \sqrt{I}] f(x) d x+[1-F(\widehat{x})]\left(\frac{E(x \mid x \geq \widehat{x})-\sqrt{I}}{2}\right)^{2}
$$

The first term on the right-hand side can in turn be reformulated such that:

$$
\begin{aligned}
\widetilde{\pi}_{L}^{c}= & \frac{1}{4} E\left(x^{2}\right)-\frac{\sqrt{I}}{2} E(x)-\frac{1}{4} E\left(x^{2} \mid x \geq \widehat{x}\right)[1-F(\widehat{x})]+\frac{\sqrt{I}}{2} E(x \mid x \geq \widehat{x})[1-F(\widehat{x})] \\
& +[1-F(\widehat{x})]\left(\frac{E(x \mid x \geq \widehat{x})-\sqrt{I}}{2}\right)^{2}
\end{aligned}
$$

Factorizing by $\frac{1}{4}$ and by $[1-F(\widehat{x})]$ when this is possible, and then simplifying, we finally obtain:

$$
\begin{aligned}
\tilde{\pi}_{L}^{c}= & \frac{1}{4}\left[E\left(x^{2}\right)-2 \sqrt{I} E(x)\right]+\frac{1-F(\widehat{x})}{4}\left[-E\left(x^{2} \mid x \geq \widehat{x}\right)+2 \sqrt{I} E(x \mid x \geq \widehat{x})+(E(x \mid x \geq \widehat{x})-\sqrt{I})^{2}\right] \\
& =\frac{1}{4}\left[E\left(x^{2}\right)-2 \sqrt{I} E(x)\right]+\frac{1-F(\widehat{x})}{4}\left[E(x \mid x \geq \widehat{x})^{2}-E\left(x^{2} \mid x \geq \widehat{x}\right)+I\right] \\
= & \frac{1}{4}\left\{E\left(x^{2}\right)-2 \sqrt{I} E(x)-[1-F(\widehat{x})][\operatorname{Var}(x \mid x \geq \widehat{x})-I]\right\}
\end{aligned}
$$


We can now compare this expression of $\widetilde{\pi}_{L}^{c}$ with $\widetilde{\pi}_{L}^{a}\left(R^{a}\right)$. We get:

$$
\begin{aligned}
\tilde{\pi}_{L}^{c} & >\widetilde{\pi}_{L}^{a}\left(R^{a}\right) \\
& \Leftrightarrow \\
E\left(x^{2}\right)-2 \sqrt{I} E(x)-[1-F(\widehat{x})][\operatorname{Var}(x \mid x \geq \widehat{x})-I] & >E(x)^{2}+I-2 \sqrt{I} E(x)
\end{aligned}
$$

Simplifying and rearranging gives:

$$
\begin{aligned}
\widetilde{\pi}_{L}^{c} & >\widetilde{\pi}_{L}^{a}\left(R^{a}\right) \\
& \Leftrightarrow \\
E\left(x^{2}\right)-E(x)^{2}-I & >[1-F(\widehat{x})][\operatorname{Var}(x \mid x \geq \widehat{x})-I] \\
& \Leftrightarrow \\
\operatorname{Var}(x)-I & >[1-F(\widehat{x})][\operatorname{Var}(x \mid x \geq \widehat{x})-I] \\
I-\operatorname{Var}(x) & <[1-F(\widehat{x})][I-\operatorname{Var}(x \mid x \geq \widehat{x})]
\end{aligned}
$$

which is the most simple expression we can obtain. It confirms the ambiguity of profit comparison when $\operatorname{Var}(x)<I<[E(x)-\underline{x}]^{2}$. 